\title{
DAMPAK PENURUNAN KADAR AIR TERHADAP RESPON FISIOLOGIS DAN BIOKIMIA PROPAGUL Rhizophora apiculata BI.
}

\author{
The Effect of Decreasing Moisture Content to the Response of \\ Physiological and Biochemical of Rhizophora apiculata Bl. Propagules \\ Asep Rohandi ${ }^{1}$ dan/and Nurin Widyani ${ }^{2)}$ \\ ${ }^{1)}$ Balai Penelitian Kehutanan Ciamis \\ Jl. Raya Ciamis-Banjar Km. 4 PO. BOX 5 Ciamis 46201 Telp. (0265) 771352 \\ ${ }^{2)}$ Balai Penelitian Teknologi Perbenihan Bogor \\ Jalan Pakuan Ciheuleut P.O. BOX. 105. Bogor 16001 Telp. (0251) 8327768
}

Naskah masuk : 1 Desember 2009; Naskah diterima : 22 September 2010

\begin{abstract}
The research is aimed at studying effect of decreasing moisture content to the response of physiological and biochemical of Rhizophora apiculata Bl. propagules. Decreasing of moisture content is done through desiccation and storage at two (2) storage room in different temperature. Decreasing propagules moisture content by desiccation for 1,2 and 3 weeks; storing the propagules conventionally. Completely randomized design was used with one factor for the first trial and two factors for the second trial (environment and period of storage). The variables of physiological observation were germination percentage, germination rate and germination value, whereas variables of biochemistry were contents of starch, fat, protein and leachate conductivity. The results showed that desiccation and storage brought about the decrease of germination viability following desiccation and storage periods. Up to 3 weeks of desiccation period, propagules moisture content was $31.72 \%$ and it did not yet show the critical moisture content and germination percentage was still very high (86.67\%). Storing of $R$. apiculata propagules with moisture content of $54.02 \%$ in ambient room $\left(28^{\circ}-29^{\circ} \mathrm{C}\right)$ could manage the germination percentage up to $29 \%$, germination rate 0.26 per etmal and germination value 0.02 for 8 weeks. Biochemical variables measured increased following desiccation and storage periods.
\end{abstract}

Keywords: Biochemistry, desiccation, deterioration, physiology, Rhizophora apiculata, storage

\begin{abstract}
ABSTRAK
Penelitian ini bertujuan untuk mempelajari dampak penurunan kadar air terhadap fisiologis dan biokimiawi propagul Rhizophora apiculata Blume. Penurunan kadar air dilakukan melalui pengeringan dan penyimpanan pada dua (2) suhu ruang simpan. Penurunan kadar air propagul dengan cara pengeringan selama 1, 2 dan 3 minggu; Penyimpanan propagul secara konvensional. Rancangan percobaan yang digunakan berupa Rancangan Acak Lengkap dengan satu faktor untuk percobaan pertama dan dua faktor untuk percobaan yang kedua (kondisi dan periode simpan). Parameter fisiologi yang diamati meliputi daya berkecambah, kecepatan berkecambah dan nilai perkecambahan, sedangkan parameter biokimia meliputi kandungan pati, lemak, protein dan daya hantar listrik. Hasil penelitian menunjukkan bahwa perlakuan pengeringan dan penyimpanan menyebabkan penurunan viabilitas propagul sejalan dengan makin lamanya periode pegeringan dan penyimpanan. Sampai pengeringan selama 3 minggu, kadar air propagul mencapai 31,72\% dan belum menunjukkan kadar air kritis dan daya berkecambah propagul masih cukup tinggi $(86,67 \%)$. Penyimpanan propagul $R$. apiculata (kadar air awal $54,02 \%$ ) dalam ruang kamar dapat mempertahankan daya berkecambah hingga $29 \%$, kecepatan berkecambah $0,26 \%$ per etmal dan nilai perkecambahan 0,02 selama 8 minggu. Kandungan biokimia propagul cenderung meningkat dengan makin lamanya periode pengeringan dan penyimpanan.
\end{abstract}

Kata kunci : Biokimia, fisiologi, kemunduran, pengeringan, penyimpanan, Rhizophora apiculata 


\section{PENDAHULUAN}

Penurunan luas hutan mangrove diakibatkan oleh beberapa faktor antara lain terjadinya bencana alam seperti tsunami, eksploitasi hutan secara berlebihan, sedimentasi, pencemaran serta konversi hutan menjadi fungsifungsi lain seperti tambak dan pemukiman. Hal tersebut menyebabkan makin menipis dan rusaknya hutan mangrove di seluruh pesisir pantai Indonesia. Menurut Arobaya dan Wanma (2006) dalam Santoso (2008), luas hutan mangrove di Indonesia sekitar 4,25 juta hektar. Sedangkan luas hutan mangrove yang dalam kondisi rusak (Hindra, 2006) diperkirakan 6,6 juta hektar (1,8 juta hektar dalam Kawasan Hutan Negara dan 4,8 juta hektar di luar Kawasan Hutan Negara (hutan milik/hutan rakyat).

Keberhasilan rehabilitasi hutan mangrove tidak terlepas dari masalah ketersediaan bibit, terutama dalam hal kesesuaian jenis, kuantitas dan kualitasnya. Rhizophora spp., terutama $R$. apiculata merupakan salah satu jenis mangrove yang umum digunakan dalam kegiatan rehabilitasi pantai dan untuk tujuan kegiatan penanaman lainnya. Beberapa permasalahan yang timbul dalam penyediaan bibit jenis ini diantaranya adalah karena benihnya bersifat rekalsitran, tidak memiliki masa dormansi, sangat sensitif terhadap pengeringan, dan memiliki viabilitas yang sangat pendek (Schmidt, 2000). Benih rekalsitran merupakan benih berkadar air tinggi sehingga sukar ditangani ketika lepas dari pohon induknya, dengan kadar air tinggi dan kondisi lingkungan bersuhu tinggi maka perkecambahan dengan segera terjadi; proses kimia dan respirasi berlangsung (Lauridsen et al., 1992). Kondisi tersebut sangat tidak menguntungkan karena pada kadar air tertentu yang relatif tinggi benih akan cepat berakar dan viabilitasnya akan cepat mengalami kemunduran sehingga mutunya menjadi sangat rendah. Menurut Chin et al. (1989), kadar air dari benih rekalsitan pada saat masak fisiologis $(50 \%-70 \%)$ jauh lebih tinggi daripada benih ortodok (30\% - 50\%). Selain itu, benih ortodok akan kering ke kadar air panen setelah masak fisiologis yaitu sekitar 15\% - 20\%. Sedangkan menurut Schmidt (2000), kadar air benih rekalsitran relatif tinggi yaitu sekitar $25 \%$ $30 \%$ dan benih ortodok relatif kering mencapai $5 \%-10 \%$ selama proses pematangan. Benih jenis ortodok yang termasuk kebanyakan jenis zona- kering dan kebanyakan jenis pioneer zona lembab tidak mempunyai level toleransi kadar air rendah. Umumnya kadar air 6\% - 8\% cukup untuk penyimpanan yang aman; kadar air lebih rendah hanya untuk penyimpanan jangka lama pada suhu sangat rendah (pada suhu di bawah nol, dikehendaki kadar air 2\% - 4\%). Untuk benih rekalsitran, tidak toleran terhadap pengeringan yang berlebihan dan harus disimpan dengan kadar air tinggi untuk waktu sependek mungkin.

Kemunduran benih merupakan semua proses perubahan yang terjadi dalam benih yang berperan dan akhirnya mengarah pada kematian benih (Byrd, 1983). Kemunduran benih yang disebabkan penurunan kadar air diindikasikan secara fisiologi dengan adanya perubahan warna benih, tertundanya perkecambahan, menurunnya toleransi terhadap kondisi simpan yang kurang sesuai, peka terhadap radiasi, menurunnya pertumbuhan kecambah dan meningkatnya pertumbuhan kecambah abnormal. Indikasi biokimia dalam benih yang mengalami kemunduran adalah terjadinya perubahan aktivitas enzim, perubahan laju respirasi, perubahan dalam cadangan makanan, perubahan dalam membran, kerusakan kromosom dan akumulasi bahan toksin (Blanche et al., 1991; Dourado and Roberts, 1984; Abdul Baki and Anderson, 1970; Anderson, 1970).

Perubahan kondisi selama penyimpanan dapat menyebabkan perubahan laju respirasi. Laju respirasi terus meningkat bila suhu lingkungan meningkat sampai suatu saat lajunya dihambat karena terjadinya hal seperti tidak aktifnya enzim, kehabisan cadangan nutrisi atau oksigen atau karena karbondioksida terakumulasi, hingga mencapai tingkat yang menghambat. Dengan mengetahui kandungan biokimia tersebut, maka viabilitas benih dapat diprediksi sehingga teknik penyimpanan atau pengujian yang tepat dapat ditetapkan.

Sehubungan dengan adanya indikasi penurunan viabilitas yang berhubungan dengan perubahan fisiologis dan biokimiawi benih, maka perlu dilakukan penelitian pengaruh pengeringan dan penyimpanan terhadap perubahan fisiologis dan biokimiawi jenis $R$. apiculata. Tujuan penelitian ini adalah untuk mengetahui dampak penurunan kadar air terhadap respon fisiologis dan biokimia propagul $R$. apiculata. Hasil penelitian diharapkan dapat merupakan upaya untuk mempertahankan mutu propagul R. apiculata sebelum disemaikan. 


\section{METODOLOGI PENELITIAN}

\section{A. Lokasi dan Waktu}

Penelitian dilaksanakan mulai bulan Januari sampai Nopember 2007 di Laboratorium Balai Penelitian Teknologi Perbenihan (BPTP) dan Laboratorium Ekofisiologi Balai Penelitian Tanaman Rempah dan Obat (Balitro), Bogor. Lokasi pengumpulan buah $R$. apiculata dilakukan di Bali, Desa Pagirigan Kecamatan Sindang Indramayu, Kecamatan Pamanukan Subang dan Baturusa Bangka Belitung.

\section{B. Bahan dan Peralatan}

Bahan yang digunakan adalah propagul Rhizophora apiculata, sedangkan alat-alat yang digunakan meliputi peralatan laboratorium seperti timbangan, oven, AC, termometer dan peralatan rumah kaca seperti bak kecambah dan alat penyiraman.

\section{Metode}

Penelitian ini dibagi dalam 2 (dua) percobaan yang meliputi : (1) Pengaruh pengeringan terhadap perubahan fisiologi dan biokimia propagul dan (2) Pengaruh penyimpanan terhadap perubahan fisiologi dan biokimia propagul (Tabel 1).

Data yang diperoleh dianalisis keragamannya (ANOVA) dan diuji perbedaannya dengan menggunakan uji jarak berganda Duncan.

Tabel (Table 1). Rancangan dan variabel percobaan (Experimental design and variables)

\begin{tabular}{|c|c|c|c|}
\hline $\begin{array}{l}\text { Percobaan } \\
\text { (Experiment) }\end{array}$ & $\begin{array}{c}\text { Rancangan } \\
\text { (Design) }\end{array}$ & $\begin{array}{c}\text { Variabel } \\
\text { (Variables) }\end{array}$ & $\begin{array}{c}\text { Keterangan } \\
\text { (Remarks) }\end{array}$ \\
\hline Percobaan 1 & $\begin{array}{l}\text { RAL dengan } 3 \text { ulangan: } \\
\text { periode pengeringan } 0,1,2 \text {, } \\
3 \text { minggu }\end{array}$ & \multirow{2}{*}{$\begin{array}{l}\text { - Fisiologi : kadar air } \\
\text { (KA), daya berkecambah } \\
\text { (DB), kecepatan } \\
\text { berkecambah dan nilai } \\
\text { perkecambahan } \\
\text { - Biokimia : pati, lemak, } \\
\text { protein dan daya hantar } \\
\text { listrik }\end{array}$} & \multirow{2}{*}{$\begin{array}{l}\text { Setiap ulangan terdiri dari } \\
30 \text { propagul : } \\
\text { - } 25 \text { propagul untuk DB } \\
\text { - } 2 \text { propagul untuk KA } \\
\text { - } 3 \text { propagul untuk } \\
\text { pengujian biokimia }\end{array}$} \\
\hline Percobaan 2 & $\begin{array}{l}\text { RAL faktorial } 2 \text { x } 6 \text { dengan } \\
3 \text { ulangan } \\
\text { - Faktor } \mathrm{A}=\text { suhu ruang } \\
\text { simpan (ruang } \\
\text { kamar/A1 }=28-29^{0} \mathrm{C} \text { dan } \\
\text { ruang AC } / \mathrm{A} 2=18-20^{\circ} \mathrm{C} \text { ) } \\
\text { - Faktor } \mathrm{B}=\text { lama } \\
\text { penyimpanan }(\mathrm{B} 0= \\
\text { kontrol, } \mathrm{B} 1=2 \mathrm{minggu} \\
\mathrm{B} 2=4 \text { minggu, } \mathrm{B} 3=6 \\
\text { minggu, } \mathrm{B} 4=8 \text { minggu } \\
\text { dan } \mathrm{B} 5=10 \text { minggu }\end{array}$ & & \\
\hline
\end{tabular}

Tabel(Table 2). Matrik perlakuan percobaan (Experimental matrix treatments)

\begin{tabular}{|c|c|c|c|c|c|c|}
\hline \multirow{2}{*}{ Faktor (Factor) A } & \multicolumn{5}{|c|}{ Faktor (Factor) B } \\
\cline { 2 - 7 } & B0 & B1 & B2 & B3 & B4 & B5 \\
\hline A1 & A1B0 & A1B1 & A1B2 & A1B3 & A1B4 & A1B5 \\
\hline A2 & A2B0 & A2B1 & A2B2 & A2B3 & A2B4 & A2B5 \\
\hline
\end{tabular}

\section{Pelaksanaan}

Kegiatan penelitian dimulai dengan tahap persiapan yang meliputi penyiapan wadah simpan berupa kardus (50 × $30 \times 20 \mathrm{~cm})$, media simpan berupa serbuk gergaji yang telah disterilkan, ruang simpan (ruang AC dan ruang kamar) yang masing-masing diukur suhu dan kelembabannya setiap 3 hari sekali selama penyimpanan dan media perkecambahan yang terdiri dari campuran pasir, tanah, kompos dengan perbandingan $1: 1: 1(\mathrm{v} / \mathrm{v})$.

Pengunduhan propagul $R$. apiculata dilakukan pada buah yang telah matang dengan ciri-ciri kotiledon berwarna coklat kemerahan atau kekuningan. Seleksi dilakukan untuk memilih propagul yang dianggap cukup baik dan memenuhi persyaratan. Propagul yang dipilih adalah propagul yang sehat dan masak, ditandai oleh warna kotiledon coklat kemerahan atau 
kekuningan, hipokotil kokoh serta bebas dari hama penyakit maupun luka mekanis.

Pengujian propagul diperlukan untuk menilai mutu fisiologi dan biokimia propagul yang diteliti, metode yang digunakan untuk uji fisiologi adalah dengan pengujian di persemaian. Sementara itu, untuk uji biokimia dilaksanakan di Balai Penelitian Tanaman Rempah dan Obat Bogor (Balitro). Penyemaian propagul $R$. apiculata dilakukan langsung pada polybag dengan cara membenamkan ujung hipokotil sedalam kurang lebih $5 \mathrm{~cm}$.

Kegiatan pemeliharaan yang dilakukan dengan penyiraman air garam dengan konsentrasi $2,5 \%$ yang dilakukan sekali selama penelitian yaitu langsung setelah penyemaian. Penyiraman dengan air tawar dilakukan secukupnya (satu hari sekali). Pencabutan/ pembersihan gulma dan penyemprotan pestisida dilakukan sesuai kebutuhan.

\section{E. Teknik Pengumpulan Data}

Data yang diamati dalam penelitian ini meliputi variabel fisiologis dan biokimiawi propagul. Variabel fisiologi meliputi pengukuran kadar air, daya berkecambah, kecepatan berkecambah, dan nilai perkecambahan. Selain variabel fisiologi, analisis juga dilakukan untuk mengetahui biokimia benih meliputi kandungan lemak benih, pati, total protein dan daya hantar listrik di Laboratorium Ekofisiologi Balitro, Bogor.

Pengukuran kadar air propagul dilakukan dengan menggunakan 2 buah contoh propagul untuk setiap perlakuan dan dilakukan dalam dua tahap. Tahap pertama merupakan tahap pra pengeringan (predrying). Pada tahap ini propagul ditimbang sehingga diperoleh berat basah, propagul kemudian dimasukkan ke dalam oven dengan suhu $130^{\circ} \mathrm{C}$ selama 5-10 menit (ISTA, 1985). Setelah dimasukkan ke dalam desikator selama 45 menit, propagul ditimbang lagi sehingga diperoleh berat kering propagul. Pada tahap kedua, sebelum dimasukkan ke oven, propagul dipotong dan dibelah. Suhu oven yang digunakan adalah $105^{\circ} \mathrm{C}$ selama $17 \mathrm{jam}$. Berat kering propagul diperoleh dengan cara menimbang propagul setelah propagul dibiarkan dalam desikator selama 45 menit.

Kadar air dihitung berdasarkan rumus yang terdapat dalam ISTA(2006), yaitu:

$$
\text { MC S1 S2 - } \frac{\text { S1 S2 }}{100}
$$

\section{Dimana :}

MC : Kadar air dalam \%

S1 : Jumlah air yang hilang pada pemanasan predrying (\%)

S2 : Jumlah air yang hilang pada pemanasan kedua $(\%)$

Daya berkecambah (DB) yaitu banyaknya persentase kecambah normal pada pengamatan selama 30 hari setelah tanam (hst), dengan persamaan sebagai berikut :

Daya Berkecambah \% $\quad \frac{\text { Jumlah kecambah normal }}{\text { Total benih yang ditabur }} \quad 100 \%$

Kecepatan berkecambah (KT) diukur berdasarkan total nilai pertambahan kecambah normal setiap hari, dengan persamaan :

$$
\mathrm{Kt}(\% / \text { hari })=\frac{\mathrm{N} 1}{\mathrm{D} 1} \quad \frac{\mathrm{N} 2}{\mathrm{D} 2} \quad \ldots \ldots \ldots . \frac{\mathrm{Nn}}{\mathrm{Dn}}
$$

Dimana :

$\mathrm{Kt} \quad$ : kecepatan perkecambahan

N1.......Nn : $\quad$ kecepatan normal pada $1,2, \ldots . .$. $\mathrm{n}$ hari setalah tanam $(\%)$

D1.......Dn : jumlah hari setelah tanam

Nilai perkecambahan (NP) atau Germination Value (GV) dihitung dengan menggunakan rumus sebagai berikut :

GV PV x FGD

PV $\frac{\% \text { Perkecambahan puncak }}{\text { Jumlah hari perkecambahan }}$

FGD $\frac{\text { \% Perkecambahan pada akhir pengamatan }}{\text { Jumlah hari uji }}$

Dimana :

GV : Nilai Perkecambahan

PV : Perkecambahan Puncak

FGD : Perkecambahan harian akhir 


\section{HASIL DAN PEMBAHASAN}

\section{A. Percobaan 1 : Pengaruh Pengeringan terhadap Perubahan Fisiologi dan Biokimia}

Pengamatan pertumbuhan propagul $R$. apiculata dilakukan setiap dua hari sekali selama 90 hari (3 bulan), sedangkan untuk pengamatan biokimia propagul dilakukan secara bertahap sesuai dengan perlakuan yang diberikan.
Hasil analisis keragaman menunjukkan bahwa pemberian perlakuan pengeringan memberikan pengaruh sangat nyata terhadap variabel kadar air (KA) dan kecepatan berkecambah $(\mathrm{Kt})$, berpengaruh nyata terhadap daya berkecambah (DB), tetapi tidak berpengaruh nyata terhadap nilai perkecambahan (NP) propagul seperti selengkapnya dicantumkan pada Tabel 3 .

Tabel (Table) 3. Rekapitulasi hasil analisis keragaman pengaruh pengeringan terhadap variabel kadar air (KA), daya berkecambah (DB), kecepatan berkecambah (Kt) dan nilai perkecambahan (NP) propagul $R$. apiculata (Summarized analysis of variance regarding the effect of desiccation duration on the moisture content, germination percentage, germination rate and germination value of $R$. apiculata seed)

\begin{tabular}{|c|l|c|}
\hline No. & \multicolumn{1}{|c|}{ Variabel (variables) } & F-hit (calculated F) \\
\hline 1. & Kadar air & $81.49^{* *}$ \\
\hline 2. & Daya berkecambah & $4.53^{*}$ \\
\hline 3. & Kecepatan berkecambah & $158.98^{* *}$ \\
\hline 4. & Nilai perkecambahan & $1.04^{\mathrm{ns}}$ \\
\hline
\end{tabular}

Keterangan (Remarks): ** : Berpengaruh sangat nyata pada selang kepercayaan 99\% (very significant at 95\% confident level) * : Berpengaruh nyata pada selang kepercayaan $95 \%$ (significant at $95 \%$ confident level) ns : Tidak berpengaruh nyata pada selang kepercayaan $95 \%$ (not significant at $95 \%$ confident level)

Hasil uji Duncan (Tabel 4) menunjukkan bahwa perlakuan pengeringan pada periode 1 minggu tidak berbeda nyata dengan tanpa pengeringan (kontrol) terhadap variabel kadar air (KA), sedangkan pada periode 2-3 minggu menunjukkan perbedaan yang sangat nyata. Kadar air merupakan faktor utama yang mempengaruhi viabilitas propagul karena pada kadar air tertentu viabilitas propagul dapat mencapai maksimum. Perlakuan pengeringan propagul memberikan pengaruh nyata terhadap variabel fisiologi propagul $R$. apiculata. Daya berkecambah, kecepatan berkecambah dan nilai perkecambahan semakin menurun dengan meningkatnya periode pengeringan propagul. Pengeringan propagul selama 1 minggu tidak menyebabkan penurunan daya berkecambah dari kontrol (tanpa penurunan) yaitu masih 100\% meskipun nilai tersebut tidak berbeda nyata dengan daya kecambah propagul pada periode penurunan selama 2 minggu (Tabel 4). Pada ketiga perlakuan tersebut daya berkecambah propagul $R$. apiculata tergolong cukup baik karena masih bisa mencapai di atas $97 \%$ (Gambar 1). Penurunan daya kecambah propagul terlihat nyata setelah penurunan selama 3 minggu
$(86,67 \%)$ yaitu sebesar $13,33 \%$. Seperti halnya pada propagul Bruguera gymnorhiza (Handayani, 2004), pengeringan propagul $R$. apiculata cukup lambat sehingga penurunan daya kecambah tidak terjadi secara drastis.

Viabilitas maksimum propagul terjadi pada kadar air $54,02 \%$ yaitu pada perlakuan tanpa pengeringan (kontrol). Hal tersebut ditunjukkan dengan dicapainya nilai tertinggi untuk semua parameter yaitu daya berkecambah sebesar $100 \%$, kecepatan berkecambah $2,57 \%$ per etmal dan nilai perkecambahan 0,19 . Meskipun cenderung terus menurun selama 3 minggu pengeringan viabilitas masih bisa dipertahankan dengan baik yaitu sebesar $86,67 \%$ dan nilai perkecambahannya tidak berbeda nyata dengan perlakuan-perlakuan lainnya.

Justice and Louis (1990) menyatakan bahwa pada kondisi kadar air yang sangat rendah atau mendekati kritis, gejala kerusakan benih akan tampak dan diikuti penurunan daya berkecambah setelah benih disimpan. Namun sampai pengeringan selama 3 minggu, daya berkecambah masih cukup tinggi $(86,67 \%)$ dan kondisi propagul masih kelihatan cukup segar. 
Tabel(Table) 4. Rekapitulasi uji jarak duncan pengaruh pengeringan terhadap parameter Daya Berkecambah (DB), Kecepatan berkecambah (KT) dan Nilai Perkecambahan (NP) propagul $R$. apiculata (Summarized of Duncan's multiple range test to the effect of desiccation on the moisture content, germination percentage, germination rate and germination value of $\mathrm{R}$. apiculata seed)

\begin{tabular}{|c|c|c|c|c|c|}
\hline \multirow{2}{*}{ No. } & $\begin{array}{c}\text { Lama } \\
\text { Pengeringan } \\
\text { (Drying period })\end{array}$ & $\begin{array}{c}\text { KA (moisture } \\
\text { content) } \\
(\%)\end{array}$ & $\begin{array}{c}\text { DB } \\
\text { (germination } \\
\text { percentage }) \\
(\%)\end{array}$ & $\begin{array}{c}\text { KT (germination } \\
\text { rate) } \\
(\% \text { per etmal) }\end{array}$ & $\begin{array}{c}\text { NP (germination } \\
\text { value) }\end{array}$ \\
\hline 1. & 0 minggu & $54.02 \mathrm{a}$ & $100.00 \mathrm{a}$ & $2.57 \mathrm{a}$ & $0.19 \mathrm{a}$ \\
\hline 2. & 1 minggu & $50.78 \mathrm{a}$ & $100.00 \mathrm{a}$ & $2.34 \mathrm{~b}$ & $0.11 \mathrm{a}$ \\
\hline 3. & 2 minggu & $40.64 \mathrm{~b}$ & $97.33 \mathrm{a}$ & $1.87 \mathrm{c}$ & $0.08 \mathrm{a}$ \\
\hline 4. & 3 minggu & $31.72 \mathrm{c}$ & $86.67 \mathrm{~b}$ & $1.38 \mathrm{~d}$ & $0.08 \mathrm{a}$ \\
\hline
\end{tabular}

Keterangan(Remarks): Angka-angka yang diikuti oleh huruf yang sama pada kolom yang sama tidak berbeda nyata pada tingkat kepercayaan $95 \%$ uji berganda Duncan (values followed by the same letters in the same column are not significantly different at $95 \%$ confident level in accordance to the Duncan's multiple range test)

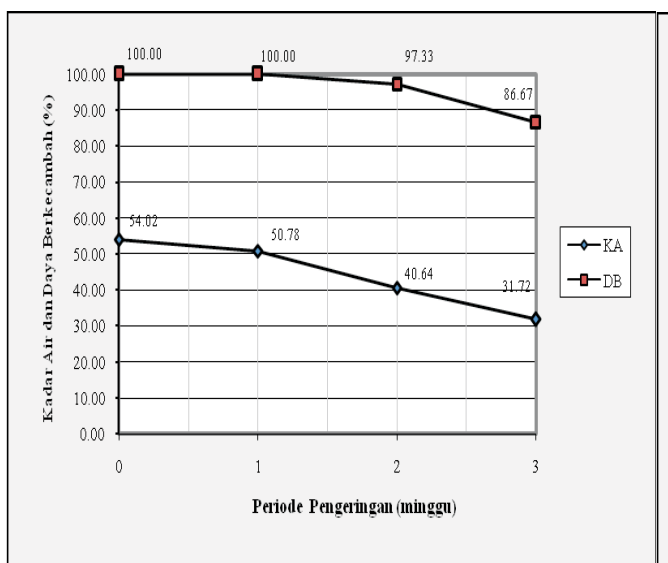

(a)

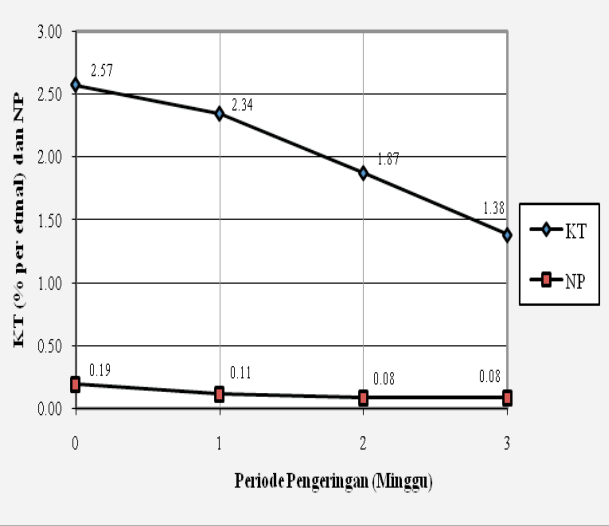

(b)

Gambar (Figure) 1. Viabilitas propagul R. apiculata pada beberapa periode pengeringan : a). kadar air (KA) dan daya berkecambah (DB) dan b). kecepatan berkecambah (KT) dan nilai perkecambahan (NP) (Viability of $R$. apiculata seeds at desiccation period a). moisture content and germination percentage and $b$ ). germination rate and germination value)

Parameter biokimia yang diamati dalam penelitian ini meliputi kadar pati, lemak, protein dan daya hantar listrik (DHL). Hasil analisis kandungan biokimia propagul pada berbagai perlakuan pengeringan selengkapnya dicantumkan pada Tabel 5.

Hasil pada Tabel 5 menunjukkan bahwa kandungan biokimia propagul $R$. apiculata yaitu pati, lemak dan protein berubah-ubah (turun naik) dengan meningkatnya waktu pengeringan meskipun semuanya lebih tinggi dibanding kontrol. Sedangkan daya hantar listrik (DHL) semakin meningkat dengan meningkatnya waktu pengeringan. Kandungan biokimia tertinggi masing-masing parameter yaitu untuk pati $27,35 \%$ ( 2 minggu), lemak $0,71 \%$ (2 minggu), protein 4,50\% (1 minggu) dan DHL 2,30 (3 minggu).

Kandungan biokimia propagul $R$. apiculata yang meliputi pati, lemak dan protein cenderung mengalami perubahan komposisi (naik turun) selama pengeringan (Gambar 2). Peningkatan kandungan karbohidrat selama pengeringan secara umum diindikasikan bahwa menguapnya air menyebabkan kandungan karbohidrat lebih pekat sehingga konsentrasinya meningkat. Menurut Nkang (1988), pengeringan yang berlebihan juga akan menyebabkan hilangnya karbohidrat baik karena polimerisasi atau koagulasi/pembekuan. 
Tabel(Table) 5. Jumlah kandungan pati, lemak, protein dan daya hantar listrik (DHL) pada berbagai perlakuan pengeringan propagul R. apiculata (Contain of carbohydrate, fat, protein and leachate conductivity of many desiccation treatments of $\mathrm{R}$. apiculata seeds)

\begin{tabular}{|c|c|c|c|c|c|}
\hline \multirow{2}{*}{ No. } & $\begin{array}{c}\text { Lama } \\
\text { Pengeringan } \\
\text { (period) }\end{array}$ & $\begin{array}{c}\text { Pati } \\
\text { (carbohydrate) } \\
(\%)\end{array}$ & $\begin{array}{c}\text { Lemak } \\
(\text { fat }) \\
(\%)\end{array}$ & $\begin{array}{c}\text { Protein } \\
\text { (protein }) \\
(\%)\end{array}$ & $\begin{array}{c}\text { DHL } \\
\text { (leachate conductivity } \\
\text { (milimhos) }\end{array}$ \\
\hline 1. & 0 minggu & 15.06 & 0.07 & 3.63 & 0.46 \\
\hline 2. & 1 minggu & 24.92 & 0.29 & 4.50 & 0.87 \\
\hline 3. & 2 minggu & 27.35 & 0.71 & 3.81 & 1.20 \\
\hline 4. & 3 minggu & 24.01 & 0.24 & 3.69 & 2.30 \\
\hline
\end{tabular}

Secara umum kandungan lemak propagul yang dianalisis, tidak mengalami perubahan secara nyata karena sampai penurunan 3 minggu viabilitas propagul masih cukup baik. Perbedaan kadar air kesetimbangan antar spesies, disebabkan oleh variasi jumlah lemak yang tersimpan. Gejala awal kerusakan dalam pengeringan benih rekalsitran adalah kebocoran membran. Kerusakan membran menyebabkan kehilangan bagian-bagian dari sel dan pelepasan enzim hidrolitik. Hal ini sering menghasilkan kerusakan luas pada organisme dan menyebabkan kematian.

Kebocoran membran berhubungan dengan transisi fase lemak (lipid phase transition). Fosfolipid membran terjadi dalam dua fase yaitu fase kristal cair (liquid crystalline phase) dan fase gel (gel phase). Peningkatan suhu dalam pengeringan di mana fase kristal cair pada membran fosfolipid berubah menjadi fase gel, yang menghasilkan peningkatan kebocoran membran selama pengeringan atau reimbibisi (Kraak, 1993 dalam Adimargono, 1997). Hal tersebut merupakan salah satu penyebab terjadinya peningkatan nilai daya hantar listrik dalam benih.

Hipotesis lain tentang rusaknya membran selama pengeringan pada jaringan yang tidak tahan pengeringan termasuk de-esterifikasi termediasi radikal (radical- mediated deesterification) atau peroksidasi dari phospholipid membran, toleransi terhadap pengeringan mungkin berhubungan dengan adanya anti oksidan yang dapat menetralkan radikal bebas dan terlarut pada lipid dari membran (Kraak, 1993 dalam Adimargono, 1997).

Analisis kandungan protein menunjukkan bahwa meskipun terjadi peningkatan pada pengeringan 1 minggu di banding kontrol (tanpa pengeringan), tetapi setelah itu kandungan protein terus mengalami penurunan sejalan dengan penurunan kadar air benih. Tatipata et al. (2004) menjelaskan bahwa kadar protein membran mitokondria menurun lebih cepat karena protein lebih peka terhadap kondisi penyimpanan yang kurang menguntungkan. Protein membran bersama fosfolipid berfungsi menjalankan fungsi membran. Menurunnya kadar fosfolipid membran akan berpengaruh terhadap penurunan fungsi membran. Menurunnya kadar fosfolipid dan protein membran mencerminkan terjadinya kemunduran benih. Hal serupa terjadi pada pengeringan Calamus spp. penurunan kadar air diikuti dengan penurunan kandungan protein dalam benih yang erat kaitannya dengan peningkatan asam amino bebas (Girija and Srinivasan, 1998).

Nilai daya hantar listrik untuk jenis propagul yang diuji cenderung mengalami peningkatan sejalan dengan meningkatnya periode pengeringan propagul. Hasil penelitian Nugroho (1998) pada jenis sengon buto menunjukkan hal yang sama, dimana daya hantar listrik semakin meningkat dengan semakin lamanya pengusangan benih.

Byrd (1983) menyatakan bahwa benih hidup mengadakan reaksi yang berbeda bila dialiri arus listrik. Benih-benih yang mati lebih permeabel dan apabila direndam dalam air maka elektrolit benih akan tercuci lebih cepat. Daya hantar listrik benih memiliki kepekaan yang tinggi dalam mendeteksi kemunduran benih, tetapi banyak faktor yang dapat mempengaruhinya seperti : (1) kerusakan mekanis pada benih, (2) kondisi kulit benih, (3) suhu dan tekanan osmotik cairan perendaman (4) tingkat imbibisi awal sebelum benih direndam dan (5) lamanya perendaman (Pian,1981; Nugroho, 1998). 

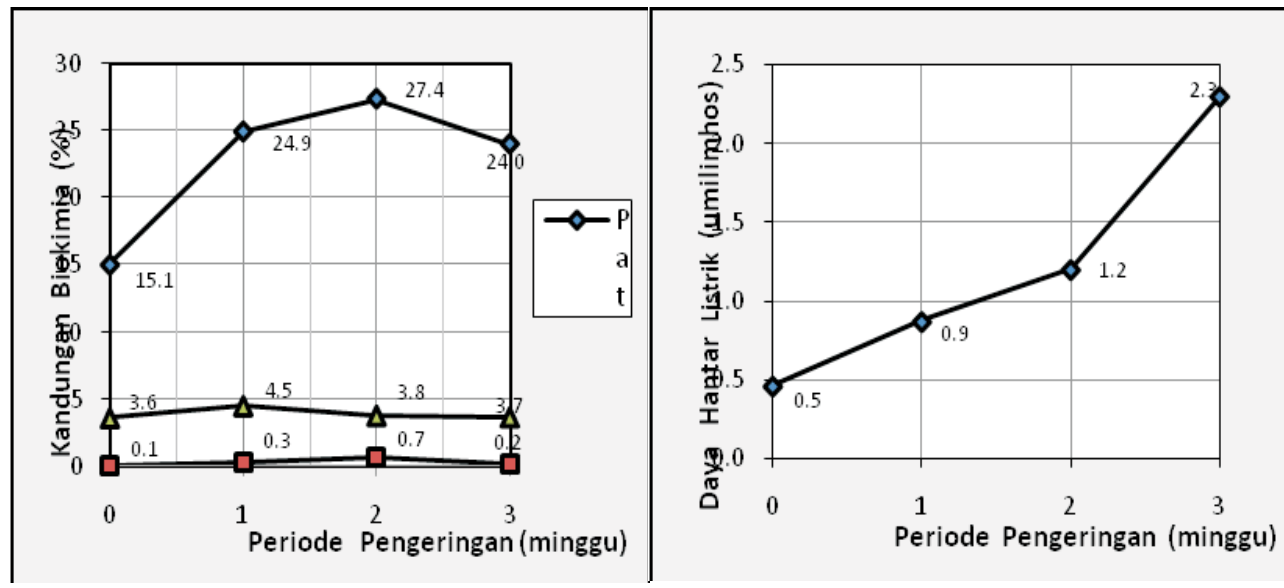

Gambar(Figure)2. Kandungan pati, lemak protein dan daya hantar listrik pada berbagai tingkat kadar air propagul $R$. apiculata (contents of carbohydrate, fat, protein and leachate conductivity at several moisture content levels of R. apiculata seeds)

\section{B. Percobaan 2 : Pengaruh Penyimpanan terhadap Perubahan Fisiologi dan Biokimia}

Hasil analisis keragaman menunjukkan bahwa pemberian faktor tunggal ruang simpan (A) dan lama penyimpanan (B) serta interaksinya
$(\mathrm{AB})$ berpengaruh sangat nyata terhadap variabel kadar air (KA), daya berkecambah (DB) dan kecepatan berkecambah (KT) serta berpengaruh nyata terhadap nilai perkecambahan (NP) propagul $R$. apiculata seperti selengkapnya dicantumkan pada Tabel 6 .

Tabel(Table) 6. Rekapitulasi hasil analisis keragaman pengaruh penyimpanan terhadap variabel Kadar Air (KA), Daya Berkecambah (DB), Kecepatan berkecambah (KT) dan Nilai Perkecambahan (NP) jenis R. apiculata (Summarized analysis of variance to the effect of storage on the moisture content, germination percentage, germination rate and germination value of $\mathrm{R}$. apiculata seeds)

\begin{tabular}{|c|c|c|c|c|}
\hline \multirow{2}{*}{$\begin{array}{c}\text { SK } \\
\text { (sourcesof } \\
\text { variation) }\end{array}$} & $\begin{array}{c}\text { KA } \\
\text { (moisture content }) \\
(\%)\end{array}$ & $\begin{array}{c}\text { DB(germination } \\
\text { percentage) } \\
(\%)\end{array}$ & $\begin{array}{c}\text { KT } \\
\text { (germination rate) } \\
(\% \text { per etmal) }\end{array}$ & $\begin{array}{c}\text { NP (germination } \\
\text { value) }\end{array}$ \\
\hline $\mathrm{A}$ & $91.39^{* *}$ & $253.10^{* *}$ & $339.69^{* *}$ & $3.19^{*}$ \\
\hline $\mathrm{B}$ & $72.01^{* *}$ & $247.51^{* *}$ & $302.95^{* *}$ & $2.51^{*}$ \\
\hline $\mathrm{A} \mathrm{B}$ & $28.68^{* *}$ & $59.30^{* *}$ & $54.13^{* *}$ & $2.44^{*}$ \\
\hline
\end{tabular}

Ket. (Remarks) : ** : Berpengaruh sangat nyata pada selang kepercayaan 99\% (very significant at 95\% confident level))

* : Berpengaruh nyata pada selang kepercayaan $95 \%$ (significant at $95 \%$ confident level)

ns : Tidak berpengaruh nyata pada selang kepercayaan $95 \%$ (not significant at $95 \%$ confident level)

Hasil uji jarak Duncan menunjukkan bahwa pengaruh lamanya penyimpanan berbeda tergantung dimana propagul disimpan (ruang simpan). Propagul $R$. apiculata mampu tumbuh sampai waktu 8 minggu dengan daya kecambah sebesar 29,33\% di ruang kamar dan tidak mampu tumbuh $(0 \%)$ pada penyimpanan 10 minggu. Pada penyimpanan di ruang $\mathrm{AC}$, propagul mampu tumbuh sampai waktu penyimpanan 4 minggu sebesar $29,33 \%$ dan setelah 6 minggu daya berkecambah propagul menjadi $0 \%$.

Hasil pengamatan perkecambahan selama 90 hari menunjukkan bahwa daya berkecambah propagul $R$. apiculata yang disimpan pada ruang $\mathrm{AC}$ menurun sangat tajam pada penyimpanan 
selama 4 minggu dan tidak mampu berkecambah pada penyimpanan 6 minggu. Sementara itu, propagul yang disimpan pada ruang kamar daya berkecambahnya menurun tajam pada penyimpanan 8 minggu dan tidak mampu berkecambah pada penyimpanan 10 minggu (Gambar 3).
Hasil penelitian Anggraini (2000) menunjukkan hasil yang sama dimana propagul $R$. apiculata dengan daya berkecambah $100 \%$ tanpa penyimpanan mengalami penurunan pada akhir pengamatan yaitu sampai periode penyimpanan 4 minggu menjadi $70,56 \%$.

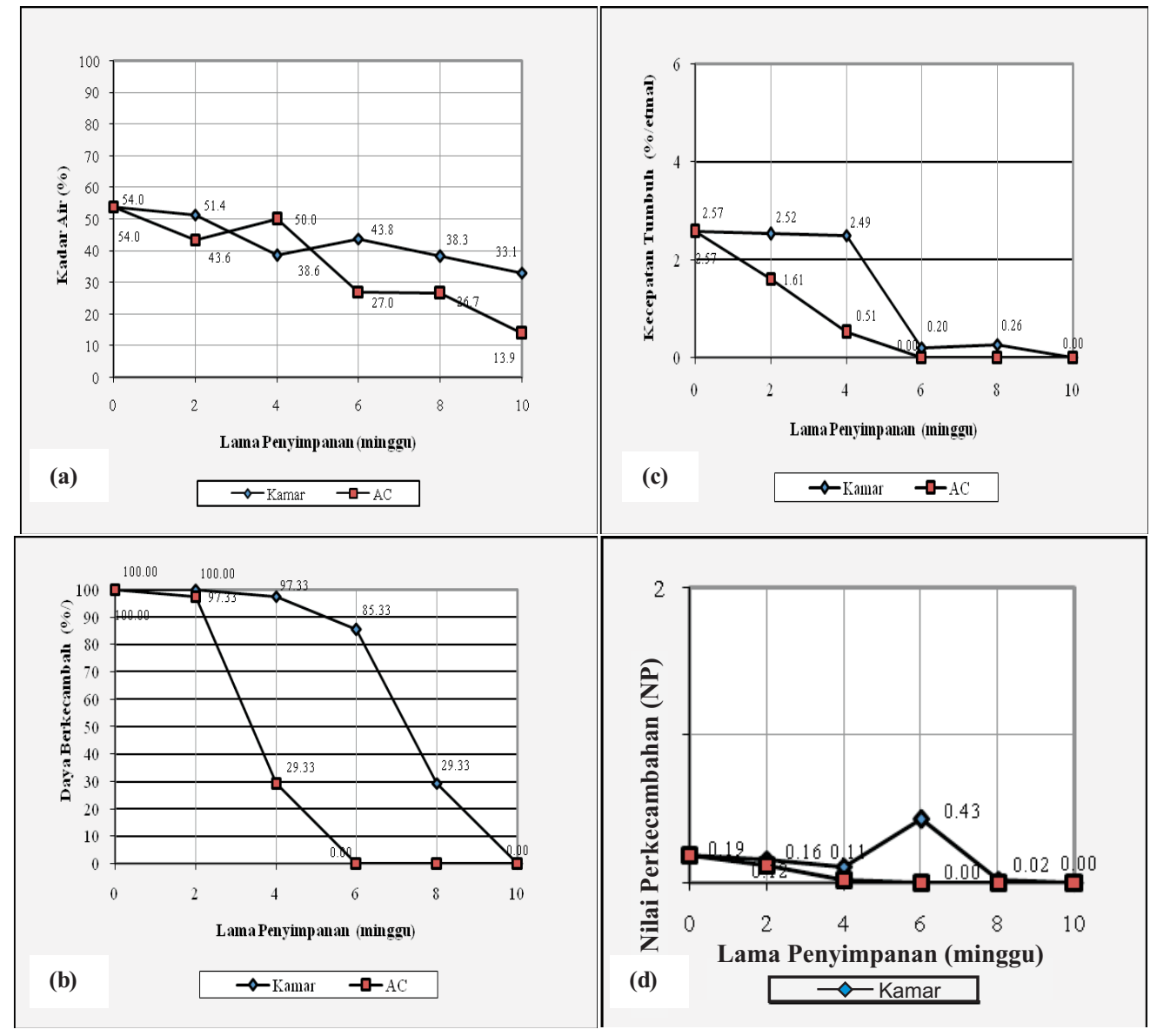

Gambar(Figure) 3. Viabilitas propagul R. apiculata pada beberapa perlakuan penyimpanan : a). Kadar air, b). Daya berkecambah, c) Kecepatan Tumbuh dan d) Nilai perkecambahan (Viability of R. apiculata seed at many storage treatment : a). Moisture content, b) Germination percentage, c) Germination rate and d) Germination value

Daya berkecambah propagul yang disimpan pada ruang kamar mengalami penurunan yang lebih lambat dibanding penyimpanan pada ruang AC (Gambar 3). Pada minggu keenam propagul yang disimpan pada ruang AC sudah tidak mampu tumbuh (menurun $100 \%$ ), sedangkan pada ruang kamar daya berkecambah propagul masih 85,33\%. Hal tersebut disebabkan pada ruang $\mathrm{AC}$ suhu dan kelembaban udara lebih rendah dibanding ruang kamar. Kondisi seperti ini menyebabkan propagul mudah mengalami kehilangan air.
Pengeringan ini merupakan faktor penyebab terjadinya kemunduran benih. Kadar air benih pada akhir periode simpan merupakan faktor yang sangat kritis sehubungan dengan pengaruhnya terhadap daya berkecambah dan viabilitas benih. Hal tersebut dikarenakan bahwa semakin lama benih disimpan maka akan menyebabkan terjadinya stres air yang menyebabkan kemunduran benih (Pammenter $e t$ al., 1994).

Selain dengan parameter daya kecambah, indikator viabilitas benih dapat dilihat 
diantaranya dari parameter kecepatan berkecambah (KT) dan nilai perkecambahan (NP). Pada perlakuan penyimpanan pada propagul $R$. apiculata (Gambar 3) menunjukkan bahwa kecepatan berkecambah dan nilai perkecambahan propagul yang langsung ditanam (tanpa penyimpanan) lebih tinggi dibandingkan setelah propagul mengalami proses penyimpanan. Hal tersebut menunjukkan bahwa pada kondisi tersebut, perkecambahan propagul berlangsung sempurna sebagai indikator bahwa vigor propagul masih bagus sehingga mampu menghadapi kondisi lingkungan yang kurang menguntungkan (sub optimum) (Sadjad, 1972). Kecepatan berkecambah dan nilai perkecambahan yang semakin menurun dengan semakin lamanya waktu penyimpanan disebabkan oleh kadar air sebagai bahan proses metabolisme dalam propagul yang semakin menurun.

Hasil analisis biokimia menunjukkan bahwa komposisi kandungan biokimia propagul selama penyimpanan propagul $R$. apiculata cenderung mengalami peningkatan dan penurunan, tetapi pada akhir penyimpanan kadar masing-masing parameter mengalami peningkatan dibanding kontrol. Hasil analisis biokimia selengkapnya dicantumkan pada Tabel 7.

Tabel (Table) 7. Jumlah kandungan pati, lemak, protein dan daya hantar listrik (DHL) pada berbagai perlakuan penyimpanan propagul $R$. apiculata (Contents of carbohydrate, fat, protein and leachate conductivity of many storage treatmenst of $\mathrm{R}$. apiculata seeds )

\begin{tabular}{|c|c|c|c|c|c|}
\hline \multirow{2}{*}{ No. } & \multirow{2}{*}{$\begin{array}{c}\text { Perlakuan } \\
\text { treatment })\end{array}$} & \multicolumn{4}{|c|}{ Variabel (variables) } \\
\cline { 3 - 6 } & $\begin{array}{c}\text { Pati } \\
\left(\begin{array}{c}\text { carbohydrate }) \\
(\%)\end{array}\right.\end{array}$ & $\begin{array}{c}\text { Lemak } \\
(\text { fat }) \\
(\%)\end{array}$ & $\begin{array}{c}\text { Protein } \\
\text { protein }) \\
(\%)\end{array}$ & $\begin{array}{c}\text { DHL } \\
\text { (leachae conductivityt) } \\
(\text { milimhos })\end{array}$ \\
\hline 1. & $\begin{array}{c}\text { Kontrol } \\
\text { (benih segar)/A1B0 }\end{array}$ & 15.06 & 0.07 & 3.63 & 0.46 \\
\hline 2. & A1B1 & 22.63 & 0.24 & 3.44 & 0.87 \\
\hline 3. & A1B2 & 24.84 & 0.20 & 3.31 & 0.89 \\
\hline 4. & A1B3 & 21.35 & 0.27 & 3.63 & 1.23 \\
\hline 5. & A1B4 & 28.03 & 0.34 & 2.59 & 0.49 \\
\hline 6. & A1B5 & 28.96 & 0.54 & 4.15 & 0.17 \\
\hline 7. & A2B0 & 15.06 & 0.07 & 3.63 & 0.46 \\
\hline 8. & A2B1 & 25.56 & 0.27 & 3.69 & 1.14 \\
\hline 9. & A2B2 & 23.24 & 0.26 & 3.56 & 1.05 \\
\hline 10. & A2B3 & 22.64 & 0.39 & 3.50 & 2.84 \\
\hline 11. & A2B4 & 25.72 & 0.10 & 3.07 & 1.37 \\
\hline 12. & A2B5 & 26.62 & 0.18 & 4.19 & 0.55 \\
\hline
\end{tabular}

Keterangan: $\mathrm{A}=$ Ruang simpan $(1=$ ruang kamar; $2=$ ruang $\mathrm{AC}), \mathrm{B}=$ Lama penyimpanan $(0=0 \mathrm{minggu} / \mathrm{kontrol} / \mathrm{benih}$ segar, $1=2$ minggu; $2=4$ minggu; $3=6$ minggu $; 4=8$ minggu dan $5=10$ minggu)

Data pada Tabel 7 menunjukkan bahwa sebelum proses penyimpanan kadar pati sebesar $15,06 \%$ dan meningkat menjadi $28,96 \%$ pada akhir penyimpanan (penyimpanan dalam ruang kamar). Kandungan pati tertinggi pada propagul R. apiculata adalah $28,96 \%$ (ruang kamar selama 10 minggu), lemak $0,54 \%$ (ruang kamar selama 10 minggu), protein $4,19 \%$ (ruang AC selama 10 minggu) dan daya hantar listrik 2,84 milimhos (Ruang AC selama 6 minggu).
Peningkatan dan penurunan kandungan biokimia propagul yaitu pati, lemak dan protein kemungkinan disebabkan oleh kondisi lingkungan yang tidak stabil atau berubah-ubah yang dapat dilihat juga dari kadar air propagul yang juga cenderung berubah-ubah selama penyimpanan. Meskipun demikian, apabila dilihat dari nilai daya hantar listrik maka terjadi kecenderungan terjadinya peningkatan dengan semakin lamanya waktu penyimpanan. 
Peningkatan daya hantar listrik menandakan terjadinya penurunan vigor propagul yang cenderung akan membocorkan bahan-bahan yang dikandungnya serta kebocoran dalam membran sel merupakan tempat kerusakan yang nyata dari kemunduran benih (Mugnisjah et al., 1994). Sadjad (1993) menyatakan bahwa daya hantar listrik bertambah besar apabila benih makin mundur akibat elektrolit yang bocor semakin besar. Hal tersebut juga didukung oleh AOSA (1983) yang menerangkan bahwa dengan semakin tingginya nilai daya hantar listrik berarti semakin besar zatzat terlarut dalam larutan perendaman. Tingginya cairan sel dalam larutan perendaman menunjukkan semakin rendahnya vigor benih. Beberapa penelitian juga telah membuktikan adanya hubungan antara kualitas benih dan kebocoran elektrolit pada benih tanaman kehutanan antara lain Pinus taeda L., P. eliotti Engelm, P. pasutris Mill, P. echinata Mill, P. strobus $L$ (Bonner, 1991) serta E. cyclocarpum dan Paraserianthes falcataria (Nugroho, 1998).

Hasil pengukuran kandungan lemak selama penyimpanan terlihat cukup bervariasi. Namun demikian, dari Tabel 7 dapat dilihat bahwa nilai kandungan lemak pada propagul segar (tanpa perlakuan) $R$. apiculata sebesar $0,07 \%$ dan lebih rendah dibandingkan benih Acacia mangium yaitu 5\% yang merupakan benih orthodok (Syamsuwida et al., 2002). Salah satu ciri benih rekalsitran menurut Sudjindro (1994) adalah tingginya kadar lemak yang dikandung, sehingga benih cepat rusak selama penyimpanan. Hal tersebut diduga oleh perbedaan karakteristik seperti tipe morfologi propagul dibandingkan benih jenis rekalsitran lainnya. Namun untuk menetapkan benih kedalam klasifikasi rekalsitran tertentu perlu kajian lebih lanjut baik dilihat sifat fisiologi maupun biokimia benih selama penyimpanan secara lebih detail.

Seringkali penyediaan benih atau bibit untuk suatu penanaman harus didatangkan dari daerah lain. Oleh karena itu, informasi penyimpanan propagul dalam penelitian ini sangat penting karena tipe propagul mangrove pada umumnya termasuk jenis rekalsitran sehingga memudahkan distribusi ke daerah yang membutuhkan dengan viabilitas propagul masih tetap terjaga baik. Berdasarkan hasil penelitian ini, untuk mengatasi terjadinya penurunan viabilitas propagul selama penyimpanan diperlukan pengaturan kelembaban $(\mathrm{RH})$ supaya tetap tinggi.

\section{KESIMPULAN}

Kesimpulan yang dapat diperoleh dari penelitian ini adalah sebagai berikut :

1. Perlakuan penyimpanan memberikan pengaruh sangat nyata terhadap perubahan fisiologis propagul $R$. apiculata dimana kelembaban udara yang rendah pada ruang $\mathrm{AC}$ sangat menurunkan daya berkecambah propagul.

2. Kondisi kritis propagul $R$. apiculata belum terlihat sampai pengeringan selama 3 minggu (KA : $31,7 \%$; DB : $86,7 \%$; KT : $1,4 \%$ per etmal dan NP: 0,08).

3. Penyimpanan propagul $R$. apiculata pada ruang kamar (suhu : $28-29^{\circ} \mathrm{C}, \mathrm{RH}: 85-95 \%$ ) pada KA awal $54 \%$ merupakan cara terbaik karena masih mampu mempertahankan daya berkecambah sampai minggu ke 8 sebesar $29,3 \%$.

4. Kandungan biokimia (lemak, pati, protein dan daya hantar listik) propagul $R$. apiculata cenderung mengalami peningkatan dengan makin lamanya periode pengeringan dan penyimpanan.

\section{DAFTAR PUSTAKA}

Abdul Baki, A.A and J.D. Anderson. 1970. Viability and leaching of sugar from germinating Barley. Crop Science, 10:31 - 34

Adimargono, S. 1997. Recalcitrant seeds, identification, and storage. Final Thesis in Tropical Plant Production. Larenstein International Agriculture College, Deventer.

Anderson, J.D. 1970. Physiological and Biochemical Differences in Deteriorating Barley Seed. Crop Science, 10: 36 - 39

Anggraini, Y.N. 2000. Pengaruh Media Simpan, Ruang Simpan dan Lama Simpan terhadap Viabilitas Propagul Rhizophora apiculata. Skripsi. Fakultas Kehutanan. Institut Pertanian Bogor. Tidak Dipublikasikan. 39 hal.

AOSA. 1983. Seed Vigor Testing Handbook. Prepared by Seed Vigor Test Committee of the Association of Official Seed Analysis. Contribution No $32.88 \mathrm{p}$

Blanche. C.A.; J.D. Hodges; A.E. Gomez and E. Gonzales. 1991. Seed chemistry of the 
Tropical Tree Vochysia hondurensis Sprague Forest Science Vol.37 No. 3:949952.

Bonner, F.T. 1991. Estimating Seed Quality of Southern Pines by Leachate Conductivity. United States Departement of Agriculture. New Orleans, Louisiana.

Byrd, H. 1983. Pedoman Teknologi Benih. PT. Pembimbing Massa. Jakarta.

Chin, H. F., B. Krishnapillay, P. C. Stanwood, 1989. Seed Moisture: Recalcitrant vs. orthodox seeds. In: Seed Moisture. Eds. Ph. C. Stanwood and N. B. McDonald, CSSA Special. Publ. No. 14, Crop Science Society ofAmerica, Madison, Wisconsin, USA.

Dourado, A.M and E.H Roberts. 1984. Chromosome alterations in stored seeds. Annals of Botany Company 54: 767 - 778.

Girija, T. and S. Srinivasan. 1998. Metabolic Changes associated with Desiccation in Calamus Seeds. IUFRO Seed Symposium Recalcitrant Seeds 12 - 15 October 1998. Kualalumpur. Malaysia.

Handayani, B.R. 2003. Pengaruh Media Simpan, Ruang Simpan dan Lama Penyimpanan terhadap Viabilitas Propagul Bruguera gymnorhyza. Skripsi. Fakultas Kehutanan. Institut Pertanian Bogor. 59 hal. Tidak Dipublikasikan.

Hindra, B. 2006. Potensi dan Kelembagaan Hutan Rakyat. Prosiding Seminar Hasil Litbang Hasil Hutan 2006 : 14-23. http://www.dephut.go.id/files/ Pot Klbg_HR.pdf. Diakses tanggal 3 September 2008.

ISTA. 1985. Seed Science and Technology. Vol. 13.Zurich, Switzerland.

ISTA. 2006. International Rules for Seed Testing. The International Seed Testing Association (ISTA) P.O. Box 308, 8303 Bassersdorf, CH - Switzerland.

Justice, O. L. dan Louis, N. Bass. 1990. Prinsip dan Praktek Penyimpanan Benih. Rajawali Pers.

Lauridsen, E.B., K. Olesen and E. Scholer. 1992. Packaging Materials for Tropical Tree Fruits and Seeds. Denmark: Humblebaek: Krogerupvej 3 A, DK-350: Danida Forest Seed Centre. $25 \mathrm{p}$.
Mugnisjah, W. Q., A. Setiawan, C. Santiwa dan Suwarto. 1994. Panduan Praktikum dan Penelitian Bidang Ilmu dan Teknologi Benih. PT. Raja Grafindo Persada. Jakarta.

Nkang, A. 1988. Some Aspects of Biochemical Basis of Viability Loss in Stored Guilfoxylia monostylis Seeds. Seed Science and Technology 16: 247-260.

Nugroho, A. A. 1998. Pendugaan Kualitas Benih Sengon Buto (Enterolobium cyclocarpum Griseb) dan Sengon Laut (Paraserianthes falcataria (L) Nielsen) Berdasarkan Uji Daya Hantar Listrik. Skripsi. Jurusan Manajemen Hutan IPB. Bogor.

Pammenter, N.W and P. Berjak. 1997. Aspect of our understanding of the biology and responses of non-orthodox seeds. In Tailor, A.G and Xue Lin Huang (eds). Progress in Seed Research. Confernce Proceedings of the $2^{\text {nd }}$ ICSST. China.

Pian, Z. A. 1981. Pengaruh Uap Etil Alkohol terhadap Viabilitas Benih Jagung (Zea mays L.) dan Pemanfaatannya untuk Menduga Daya Simpan. Disertasi Doktor Fakultas Pascasarjana IPB. Bogor.

Sadjad, S. 1972. Kertas Merang untuk Uji Viabilitas Benih di Indonesia. Disertasi Fakultas Pascasarjana IPB. Bogor. Tidak dipublikasikan.

1993. Dari Benih Kepada Benih. PT. Gramedia Widiasarana Indonesia. Jakarta.

Santoso, U. 2008. Hutan Mangrove, Permasalahan dan Solusinya. http://uripsantoso.wordpress.com/2008/0 4/03/hutan-mangrove-permasalahan-dansolusinya/. Diakses tanggal 3 September 2008.

Schmidt, L. 2000. Pedoman Penanganan Benih Tanaman Hutan Tropis dan Sub Tropis. Direktorat Jenderal Rehabilitasi Lahan dan Perhutanan Sosial, Departemen Kehutanan bekerjasama dengan Indonesia Forest Seed Project (IFSP). Jakarta.

Sudjindro. 1994. Indikasi Kemunduran Viabilitas Oleh Dampak Guncangan Pada Benih Kenaf (Hibiscus cannabinus L.). Disertasi Program Pasca Sarjana. IPB. Tidak dipublikasikan. 
Syamsuwida, D., Naning Y., Enok, R.K.; Adang M dan Endang I. 2002. Biokimia Benih: Kemunduran benih yang disebabkan oleh perubahan fisiologi dan biokimia benih orthodok. LHP No. 375. BPPTP. Bogor. Tidak dipublikasikan.
Tatipata, A., Prapto Yudono, A. Purwantoro dan Woerjono Mangoendidjojo. 2004. Kajian Aspek Fisiologi dan Biokimia Deteriorasi Benih Kedelai dalam Penyimpanan. Jurnal Ilmu Pertanian Vol. 11 No. 2, 2004 : 76-87. Yogyakarta. 